\title{
Disinfection of Fertile Eggs of Free-Range Poultry with Essential Oils
}

\author{
Desinfecção De Ovos Férteis De Aves Caipiras Com Óleos Essenciais
}

\author{
NOGUEIRA, Wedson Carlos Lima ${ }^{1}$; PENA, Agda Caroline Silva ${ }^{1}$; SOUZA, Cintya Neves de ${ }^{1}$; \\ AZEVEDO, Isabela Lorena ${ }^{2}$; FARIAFILHO, Daniel Emygdio ${ }^{3}$; ALMEIDA, Anna Christinade ${ }^{1}$ \\ ${ }^{1}$ Federal University of Minas Gerais, Center for Research in Agricultural Sciences, Montes \\ Claros, Minas Gerais, Brazil. \\ ${ }^{2}$ Federal Institute of Education, Science and Technology of Bahia, Senhor do Bonfim, Bahia, \\ Brazil. \\ ${ }^{3}$ University of São Paulo, Faculty of Animal Science and Food Engineering, Pirassununga, São \\ Paulo, Brazil. \\ "Corresponding author: wedsonlima3@yahoo.com.br
}

\section{SUMMARY}

The effect of the disinfection of fertile eggs of free-range poultry with essential oils from Cymbopogon flexuosus and Lippia rotundifolia was evaluated. The treatments applied to the eggs were $\left(\mathrm{v} \mathrm{v}^{-1}\right): 1 \%$ essential oil from C. flexuosus (CF), $1 \%$ essential oil from $L$. rotundifolia(LR), $0.1 \%$ $\mathrm{CF}+\mathrm{LR}$, and $0.1 \%$ quaternary ammonia (QA) (positive control). The eggs were incubated for 21 days, the birds from hatched eggs were counted and weighed, and not hatched eggs were opened and examined macroscopically to determine egg fertility, and embryonic death time. The antimicrobial action of the essential oils was determined through quantitative analyses, considering aerobic mesophylls, filamentous fungi, yeasts, and total coliforms. Mortality was high in the treatments, especially in the treatment with essential oil from $C$. flexuosus. The highest hatchability was found in the treatment with QA. The treatments with singly or combined essential oils were more efficient in decreasing microbial count than QA. The essential oils from $C$. flexuosus and $L$. rotundifolia reduced the microbial load of fertile eggs of the free-range poultry evaluated.

Keywords: antimicrobial, hatchability, embryo, incubation

\section{RESUMO}

O presente estudo investigou o efeito da desinfecção de ovos férteis de aves caipiras com o uso de óleos essenciais de capim limão (Cymbopogon flexuosus) e chá-depedestre (Lippia rotundifolia). Aplicaramse os seguintes tratamentos nos ovos selecionados: $1 \%(\mathrm{v} / \mathrm{v})$ óleo essencial de capim limão (CL), chá-de-pedestre (CP), associação (CL + CP) e $0,1 \%(\mathrm{v} / \mathrm{v})$ de amônia quaternária (AQ) (controle positivo). Os ovos foram distribuídos em incubadora e após 21 dias, as aves eclodidas foram contadas e pesadas e os ovos não eclodidos foram quebrados e examinados macroscopicamente para a determinação da fertilidade e o momento da morte embrionária. Determinou-se a ação antimicrobiana dos óleos através das análises quantitativas de mesófilos aeróbios, fungos filamentosos e leveduras e coliformes totais. A mortalidade foi elevada nos tratamentos, a distribuição de mortes nas classes foi superior no tratamento com capim limão. A maior eclodibilidade ocorreu no tratamento com a amônia quaternária. Evidenciou-se a redução na contagem microbiana na aplicação do óleo essencial individualmente ou em associação, superando a aplicação com AQ. Os óleos essenciais de capim limão (Cymbopogon flexuosus) e chá-de-pedestre (Lippia rotundifolia) promoveram a 
Rev. Bras. Saúde Prod. Anim., Salvador, v.20, 01 -08, e0822019, 2019 http://dx.doi.org/10.1590/S1519-9940200822019

redução da carga microbiana de ovos férteis de aves caipiras.
ISSN 15199940

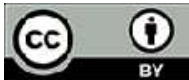

Palavras-chave:

antimicrobiano, eclodibilidade, embrião, incubação 


\section{INTRODUCTION}

The use of antimicrobials in poultry farming results in high zootechnical indexes and positive impacts on the poultry production chain. However, the banning of many antimicrobial performance enhancers increased the search for alternatives.

Contamination of fertile eggs causes large decreases in productive indexes of hatcheries and high economic losses (Scott \& Swetnam, 1993). Producers face several challenges from posture to hatching, thus, a proper management of fertile eggs is essential during these phases (Decuypere et al., 2001).

Biosecurity in poultry houses and hatcheries should be a priority for poultry farmers. Several disinfectants and application methods are available on the market; however, their efficiency is questionable due to considerable resistance of the microorganisms, and egg losses due to contamination at the poultry houseand during the incubation process.

Quaternary ammonia is one of the main commonly used disinfectants; it has high bactericidal potential and low toxicity (Grezzi, 2006; Spinosa et al., 2006). However, its action is considerably reduced in the presence of organic matter (Jaenisch et al., 2010). Moreover, regular use of disinfectants is associated with food contamination due to residues found in products of animal origin.

The interest in using essential oils has been increasing due to their antimicrobial properties, and because they are accepted by biosafety programs. Antimicrobial activity of essential oils has been reported by Adukwu et al. (2012), Sinha et al. (2014), Souza et al. (2014), Azevedo et al. (2016), and Assis et al. (2017). In this context, the objective of the present study was to evaluate the effect of the disinfection of fertile eggs of free-range poultry with essential oils from Cymbopogon Flexuosus and Lippia Rotundifolia.

\section{MATERIAL AND METHODS}

The experiment was conducted at the Institute of Agrarian Sciences of the Federal University of Minas Gerais, in Montes Claros, MG, Brazil. All procedures were performed in accordance with ethical principles and approved by the ethical committee for the use of animals (Protocol: 102/2013) of the Federal University of Minas Gerais.

The essential oil from Cymbopogon Flexuosus was purchased from the company Ferquima Indústria e Comércio Ltda., in Vargem Grande Paulista, SP, Brazil, and the essential oil from Lippia Rotundifolia was purchased from cooperative producers of the Vale do Jequitinhonha University Foundation, in the district of Serro, in São Gonçalo do Rio das Pedras, MG, Brazil. Both essential oils were extracted by steam distillation.

According to the analysis of gas chromatography coupled to mass spectrometry performed by Azevedo et al. (2016), the main component of the essential oil from $C$. flexuosus is citral $(77.42 \%)$, and a mixture of neral $(\beta-$ Citral) and geranial ( $\alpha$-Citral) isomers; and the main component of the essential oil from $L$. rotundifolia is $\beta$-myrcene (15.52\%).

Eggs from free-range poultry of unknown breed collected in a noncommercial farm were incubated. Eggs contaminated with feces or presenting cracks were discarded. The collections were carried out twice a day and the 
eggs were stored for up to five days under environmental conditions (temperature of $23-25{ }^{\circ} \mathrm{C}$ and relative humidityof $70 \%)$. The treatments applied to the eggs were $\left(\mathrm{v} \mathrm{v}^{-1}\right): 1 \%$ essential oil from C. flexuosus (CF), $1 \%$ essential oil from $L$. rotundifolia (LR), $\mathrm{CF}+\mathrm{LR}$, and $0.1 \%$ quaternary ammonia (QA) (positive control).

The eggs were completely immersed (10 seconds at $23{ }^{\circ} \mathrm{C}$ ) in the solutions with the disinfectants and left to dry for 30 minutes. They were then homogeneously distributed in a randomized block design with four replications of 30 eggs. One incubator (Premium Ecologica IP120, Belo Horizonte, Brazil) was used for each treatment. The eggs were incubated at temperature of $37.5^{\circ} \mathrm{C}$ with relative air humidityof $60 \%$ for 18 days, and then the incubators were changed to birth conditions-temperature of $37.3{ }^{\circ} \mathrm{C}$ and relative air humidity of $75 \%$ - up to the 21 days (504 hours).The birds from hatched eggs were counted and weighed, and not hatched eggs were opened and examined macroscopically to determine egg fertility, and embryonic death time, distinguishing their mortality in early (0-4 days), intermediate (5-17 days), and late (1821 days), according to Boleli(2003). Hatchability was determined by subtracting the number of infertile eggs from the total incubated eggs, and dividing the total number of birds born by total fertile eggs.

The microbiological quality of the eggshells after application of the treatments was analyzed through quantitative analyses, considering aerobic mesophylls, filamentous fungi, yeasts, and total coliforms. Three eggs of each treatment were placed in sterile plastic bags containing $0.1 \%$ peptone water at ratio of $1: 1$, using the surface wash technique. The solution was diluted up to $10^{3}$, and $0.1 \mathrm{~mL}$ of the dilutions were streaked on Petri dishes containing plate count agar (PCA), and potato dextrose agar (PDA) to quantify aerobic mesophylls, and yeasts and filamentous fungi, respectively. Total coliforms were quantified by the plating technique with overlay of violet red bile agar (VRBA). Plates with PCA and with VRBA were incubated at $37{ }^{\circ} \mathrm{C}$ for 48 hours, and plates with PDA were incubated at $28{ }^{\circ} \mathrm{C}$ for five days. The colonies formed were then counted and expressed in colony forming units (CFU) per gram of egg. A negative control with eggs without disinfection was also evaluated. The analyses were performed in triplicate, totalizing 45 eggs, according to the methodology described by Silva et al. (2010).

The data were subjected to analysis of variance; all percentage data were transformed into sine-arc, and microbial counts were transformed into $\log _{10}$. The means that differed statistically were compared by the Tukey's test $(p<0.05)$.

\section{RESULTS AND DISCUSSION}

The incubation indexes and embryodiagnosis are presented in Table 1 . The treatments affected significantly $(p<0.05)$ the hatchability of the eggs. Eggs treated with essential oil from Cymbopogon Flexuosus(CF) had the lowest hatchability, and those treated with quaternary ammonia (QA) had the best result, which presented $20 \%$ higher hatchability. Eggs treated with essential oil from Lippia Rotundifolia(LR) had similar hatchability to that of those treated with $\mathrm{CF}+\mathrm{LR}$. The treatments resulted in similar $(p<0.05)$ early mortality, however, this class presented high mortality compared to standard values for hatcheries. 
Table1. Disinfection of eggs with essential oils, and incubation indexes.

\begin{tabular}{|c|c|c|c|c|c|}
\hline Variables & $\begin{array}{l}\text { Quaternary } \\
\text { ammonia } \\
\left(0.1 \% \mathrm{v} \mathrm{v}^{-1}\right)\end{array}$ & $\begin{array}{l}\text { Cymbopogon } \\
\text { Flexuosus } \\
\left(1 \% \mathrm{v} \mathrm{v}^{-1}\right)\end{array}$ & $\begin{array}{l}\text { Lippia } \\
\text { rotundifolia } \\
\left(1 \% \mathrm{v} \mathrm{v}^{-1}\right)\end{array}$ & $\begin{array}{c}\text { C. flexuosus } \\
+ \\
\text { L.rotundifolia }(1 \\
\left.\% \mathrm{v} \mathrm{v}^{-1}\right)\end{array}$ & $\begin{array}{c}p- \\
\text { value }\end{array}$ \\
\hline Hatchability (\%) & $47.50^{\mathrm{a}} \pm 0.0$ & $27.90^{\mathrm{c}} \pm 1.7$ & $31.66^{\mathrm{b}} \pm 1.6$ & $31.66^{\mathrm{b}} \pm 1.7$ & $\begin{array}{c}<0.00 \\
1\end{array}$ \\
\hline $\begin{array}{c}\text { Early mortality }(\%) \\
\text { Intermediate mortality }(\%)\end{array}$ & $\begin{array}{c}27.39^{\text {ns }} \pm 2.4 \\
7.04^{\text {ab }} \pm 8.7\end{array}$ & $\begin{array}{l}14.32^{\text {ns }} \pm 12.7 \\
18.74^{\mathrm{a}} \pm 11.3\end{array}$ & $\begin{array}{c}29.61^{\mathrm{ns}} \pm 6.3 \\
1.00^{\mathrm{b}} \pm 0.1\end{array}$ & $\begin{array}{c}19.87^{\mathrm{ns}} \pm 7.2 \\
2.5^{\mathrm{b}} \pm 5.0\end{array}$ & $\begin{array}{l}0.400 \\
0.019\end{array}$ \\
\hline Late mortality $(\%)$ & $7.04^{\mathrm{c}} \pm 4.7$ & $34.68^{\mathrm{a}} \pm 1.5$ & $17.01^{\mathrm{bc}} \pm 11.5$ & $22.60^{\mathrm{ab}} \pm 5.2$ & $\begin{array}{c}<0.00 \\
1\end{array}$ \\
\hline $\begin{array}{l}\text { Total mortality (\%) } \\
\text { Weight at birth (g) }\end{array}$ & $\begin{array}{l}41.47^{\mathrm{b}} \pm 18.6 \\
44.89^{\mathrm{ns}} \pm 1.1\end{array}$ & $\begin{array}{c}67.58^{\mathrm{a}} \pm 3.6 \\
46.64^{\mathrm{ns}} \pm 2.5\end{array}$ & $\begin{array}{c}46.63^{\mathrm{ab}} \pm 15.4 \\
46.86^{\mathrm{ns}} \pm 6.0\end{array}$ & $\begin{array}{l}44.97^{\mathrm{ab}} \pm 4.1 \\
43.60^{\mathrm{ns}} \pm 2.2\end{array}$ & $\begin{array}{l}0.044 \\
0.632\end{array}$ \\
\hline
\end{tabular}

Means followed by the same letters in the rows do not differ by the Tukey's test $(p<0.05) ;^{\text {ns }}=$ not significant.

Total mortality was high in all treatments; the number of deaths was high in eggs treated with $\mathrm{CF}$, differing only from the control group. Birds from eggs treated with essential oils presented no difference in weight at birth. Yldrim et al. (2003) found no differences in incubation indexes and mortality in eggs treated with essential oil from Origanum vulgare L. compared to eggs treated with formaldehyde. QA is a surface disinfectant widely used in hatcheries, however, its use is restricted due to presence of organic matter (Jaenisch et al., 2010). The effectiveness of egg disinfection in the different treatments may have been compromised due to the hygienic conditions of the eggs, since they did not undergo any other cleaning process prior to disinfection. Only eggs with excess organic matter on the eggshell were discarded, making a difficult condition for the disinfectants.

The egg immersion technique may have affected the hatching rate of fertile eggs. The ideal time and temperature for hatching differ among studies
(Proudfoot et al., 1985); however, the method applied intended to promote the viability of embryos (Yldrim et al., 2003). The immersion technic should not affect excessively the hatching rate, since it could compromise the eggshell disinfection process (Mauldin, 2002).

The high mortality rates found may be due to environmental conditions prior to incubation, or immersion time during the disinfectant application process. Egg contamination by bacteria occurs soon after posture (Wall et al., 2008), which can also lead to internal contamination of the egg by migration of bacteria from the surface of the eggshell (De Reu et al., 2006b), affecting incubation rates.

The hatching rate may also have been affected by the egg handling conditions, egg storage (high temperatures) and storage time conditions in the poultry house, and the age of the birds, which were, on average, more than 100 weeks old.

The antimicrobial activity of the essential oils on the microorganisms on the eggshells is presented in Table 2. 
Table2.Antimicrobial activity of the essential oils on the microorganisms on the eggshells

\begin{tabular}{lccc}
\hline Treatments & Fungi & Coliforms & Mesophylls \\
\hline Negative control without disinfection & $2.55^{\mathrm{a}} \pm 0.2$ & $1.86^{\mathrm{ab}} \pm 0.7$ & $5.45^{\mathrm{a}} \pm 0.7$ \\
Quaternary ammonia $\left(0.1 \% \mathrm{v} \mathrm{v}^{-1}\right)$ & $2.15^{\mathrm{b}} \pm 0.1$ & $2.62^{\mathrm{a}} \pm 1.3$ & $4.76^{\mathrm{a}} \pm 0.7$ \\
Cymbopogon flexuosus $(\mathrm{CF})\left(0.1 \% \mathrm{v} \mathrm{v}^{-1}\right)$ & $2.00^{\mathrm{b}} \pm 0.1$ & $1.72^{\mathrm{ab}} \pm 0.6$ & $3.94^{\mathrm{b}} \pm 0.2$ \\
Lippia rotundifolia $(\mathrm{LR})\left(0.1 \% \mathrm{v} \mathrm{v}^{-1}\right)$ & $2.10^{\mathrm{b}} \pm 0.2$ & $1.05^{\mathrm{b}} \pm 0.1$ & $3.86^{\mathrm{b}} \pm 0.5$ \\
$\mathrm{CF}+\mathrm{LR}\left(0.1 \% \mathrm{v} \mathrm{v}^{-1}\right)$ & $2.00^{\mathrm{b}} \pm 0.1$ & $1.06^{\mathrm{b}} \pm 0.1$ & $4.06^{\mathrm{b}} \pm 0.1$ \\
$p$-value & 0.003 & 0.007 & 0.015 \\
Coefficient of variation $(\%)$ & 6.32 & 27.43 & 11.58 \\
\hline Means followed by the same letters in the columns do not differ by the Tukey's test $(p<0.05) ;{ }^{\mathrm{ns}}=$ not \\
significant.
\end{tabular}

The essential oils promoted disinfection of eggshells of the evaluated free-range poultry. The singly or combined applications of essential oils reduced the microorganism counts when compared to the QA; however, the treatments presented no significant difference ( $p>0.05$ ). The disinfection with CF+LR was lower compared to that of treatments with essential oils applied singly.

Although quaternary ammonia is usually used for disinfection of fertile eggs in hatcheries (Cony et al., 2008), it presented higher total bacterial counts than the other treatments. Most eggs had high organic matter load, which may have decreased the disinfectant action. Jaenisch et al (2010) attribute a reduction in disinfectant activity to the presence of organic matter and other compounds on the surface of the eggshells.

The disinfection of fertile eggs with essential oils for incubation showed a satisfactory reduction of microorganisms and can be recommended as an alternative to current disinfectants. Despite the conditions of the experiment, the antimicrobial activity was evidenced by the significant reduction in total microorganism counts.

The antimicrobial activity of essential oils from $C$. flexuosus and $L$. rotundifolia have been confirmed by Adukwu et al. (2012), Millezi et al. (2012), Azevedo et al. (2016), and Assis et al. (2017). Copur et al. (2010) evaluated essential oil from $O$. vulgare and found a disinfecting effect on broiler eggs, with reduction of total bacteria, and fungi and yeasts when performing fumigation of this essential oil at concentrations of 0.55 and 0.75 $\mu \mathrm{L} \mathrm{cm}^{-3}$, compared to the control and to the use of formaldehyde; they emphasized the potential of this natural disinfectant for hatcheries.

The use of essential oils for disinfection of fertile eggs is a promising antimicrobial alternative to conventional disinfectants used in hatcheries. Thus, studies have evaluated different plant extracts and their associations, bird species, egg handling conditions, and situations that are commonly found in the poultry production.

The essential oils from $C$. flexuosus and L. rotundifolia reduced the microbial load of fertile eggs of free-range poultry, and their application as disinfectant is recommended for hatcheries. 


\section{REFERENCES}

ADUKWU, E.C.; ALLEN, S.C.H.; PHILLIPS, C.A. The antibiofilm activity of lemongrass (Cymbopogon Flexuosus) and grapefruit (Citrus paradisi) essential oils against five strains of Staphylococcus aureus. Journal of Applied Microbiology, v.113, p.1217-1227, 2012.

AZEVEDO, I.L.; ALMEIDA, A.C.; MARTINS, E.R.; NOGUEIRA, W.C.L.; FARIA FILHO, D.E.; OLIVEIRA, S.P.; PRATES, J.P.B.; SOUZA, C.N. Eficácia in vitro do óleoessencial de capim-limão (Cymbopogonflexuosus steud. wats.) frente a bactériasentéricas de origemavícola. Acta Veterinaria Brasilica, v.10, p.25-31,2016.

BERTECHINI, A.G. Nutrição de monogástricos. Lavras: UFLA, 301, p.2006.

BOLELI, I. C. Estresse, mortalidade e malformações embrionárias. In: MACARI. M.; GONZALES, E. Manejo da incubação. Campinas: FACTA, p. 394-434, 2003.

CONY, H.C.; VIEIRA, S.L.; BERRES, J.; GOMES, H.A.; CONEGLIAN, J.L.B.; FREITAS, D.M. Immersion and pulverization techniques with different disinfectants above hatchin eggs. Ciência Rural, v.38, n.5, p.1407-1412, 2008.

COPUR, G.; ARSLAN, M.; DURU, M.; BAYLAN, M.; CANOGULLARI, S.; AKSAN, E. Use of oregano (Origanumonites L.) essential oil as hatching egg disinfectant. African Journal of Biotechnology, v. 8, p.2531-2538, 2010.
DECUYPERE, E.; TONA, K.; BRUGGEMAN, V. The day-old chick: A crucial hinge between breeders and broilers. World's Poultry Science Journal, Beekbergen, v.57, n.1, p.127138, 2001.

DE REU, K.; GRIJSPEERDT, K.; GRIJSPEERDT, L.; HERMAN, L.; EYNDRICKX, M.; UYTTENDAELE, M.; DEBEVERE, J.; PUTIRULAN, F.F.; BOLDER, N. M. The effect of a commercial UV disinfection system on bacterial load of shell eggs. Letters in Applied Microbiology, v.44, p.144148, 2006.

GREZZI, G.G. Biofilms - Technical Seminar on Disinfection, Atlanta 2006 Maris P. Modes of action of disinfectants. Revue Scientifique Et Technique (International Office Of Epizootics, v.14, n.1, p.47-55, 1995.

JAENISCH, F.R.F.; KUCHIISHI, S.S.; COLDEBELLA, A. Antibacterial activity of disinfectants for use in organic poultry keeping. Ciência Rural, v.40, n.2, p.384-388, 2010.

MAULDIN, J.M. Maintaining hatching egg quality. In: BELL, D.D.;

WEAVER, W.D. Commercial chicken meat and egg production. Norwell:

Kluwer Academic, 5ed, p.707-725, 2002.

MILLEZI, A.F.; BAPTISTA, N.N.; CAIXETA, D.S.; ROSSONI, D.F.; CARDOSO, M.G.; PICCOLI, R.H. Caracterização química e atividade antibacteriana de óleos essenciais de plantas condimentares e medicinais contra Staphylococcus aureus e Escherichia coli. Revista Brasileira de Plantas Medicinais, p.18-24. 2014. 
PROUDFOOT, F.G.; NASH, D.M.; HUIAN, H.W. Effects of glutaraldehyde-surfactant solution on the hatchability of the hen's egg.

Poultry Science, v.64, n.12, p.24002402, 1985.

RUI, B.R.; ANGRIMANI, D.S.R.; CRUZ, L.V.; MACHADO, T.L.; LOPES, H.C.; The main disinfection methods and antiseptic used in poultry production: a review. Departamento de Veterinária e Produção Animal DVPA. Revista Científica Eletrônica de Medicina Veterinária, n. 16, 2011.

SCOTT, T.A.; SWETNAM, C. Screening sanitizing agents and methods of application for hatching eggs I. Environmental and User Friendliness. Journal of Applied Poultry Research, v. 2, p.1-6, 1993.

SINHA, S.; JOTHIRAMAJAYAM, M.; GHOSH, M.; MUKHERJEE, A.

Evaluation of toxicity of essential oils palmarosa, citronella, lemongrass and vetiver in human lymphocytes.

Foodand Chemical Toxicology, v.68, p.71-77, 2014.

SILVA, N.; JUNQUEIRA, V.C.A.; SILVEIRA, N.F.A; TANIWAKI, M.H; SANTOS, R.F.S.; GOMES, R.A.R. Manual de métodos de análise microbiológica de alimentos e água. $4^{\mathrm{a}}$ edição - São Paulo. Livraria Varela, 2010.

SOUZA, D.S.; ALMEIDA, A.C.; ANDRADE, V.A.; MARCELO, N.A.; AZEVEDO, I.L.; MARTINS, E.R.; FIGUEIREDO, L.S. Atividade antimicrobiana do óleo essencial de Lippiaoriganoides e Lippiaroduntifol i $a$ frente à enterobactérias isoladas de aves. Arquivo Brasileiro de Medicina
Veterinaria e Zootecnia, v.67, p.940944, 2015.

SPINOSA, H.; GORNIAK, S.; BERNARDI, M. Farmacologia Aplicada à Medicina Veterinária, 4 . ed., Cap. 35, p. 441-447, Rio de Janeiro: Guanabara Koogan, 2006.

WALL, H.R.; TAUSON, R.; SORGJERD, S. Bacterial contamination of eggshells in furnished and conventional cages. The Journal of Applied Poultry Research, v.17, n.1, p.11-16, 2008.

YILDIRIM I.; OZSAN R.; YETISIR R. The use of oregano (Origanum vulgare $L$.) essential oil as alternative hatching egg disinfectant versus formaldehyde fumigation in quails (Coturnixcoturnix japonica) eggs. Food Control, v.5, p.367-370, 2003. 